IНТЕРМАРУМ: історія, політика, культура. - Вип. 8.

UDC 94(477)-054.7 "1945/1950"

DOI 10.35433/history. 112012

Podobied Olena, Doctor of Historical Sciences, Associate Professor, Associate Professor of the Department of Source Studies and Special Historical Sciences, National Pedagogical Dragomanov University o.a.podobyed@npu.edu.ua ORCID: https://orcid.org/0000-0002-7819-1439 Researcher ID: AAA-1227-2020

\title{
THE DISPLACED PERSONS ERA IN THE PERCEPTION OF THE CHILD AND THE SCIENTIST
}

Review: Larissa Zaleska Onyshkevych. Bombs, Borders, and Two Right Shoes. World War II Through the Eyes of a Refugee Child. Lviv: Litopys publ., 2018. 258 p.

It is proved that the book of memoirs by Larysa Zaleska Onyshkevych is a valuable source on the history of Displaced Persons and refugees from Ukraine in post war West Germany. We can learn from its pages how refugee children lived, what they felt, what they dreamed about, what they were afraid of during the DP era, what factors influenced the formation of their worldview and civic position.

Key words: Larysa Zaleska Onyshkevych, memoirs, DP era, West Germany.

Ukraine has published more than one volume of memoirs about the Displaced Persons (DP) era over the past decade. That was a period in the world history after World War II when many refugees and displaced persons from Ukraine and other European countries found themselves in West Germany. The insight of Larissa Zaleska Onyshkevych's book of memoirs "Bombs, Borders and Two Right Shoes. World War II Through the Eyes of a Refugee Child", the grasping of the problem in psychological, philosophical contexts and its human dimension makes it stand out favorably among the bulk of this kind of literature.

Larissa Zaleska Onyshkevych is a literary critic, a Doctor of Philosophy in University of Pennsylvania, the chairwoman of the 210 
INTERMARUM: history, policy, culture. - Issue 8.

Shevchenko Scientific Society in the USA (2000-2006), a member of the National Writers' Union of Ukraine (1993), a Doctor Habilitatus of the Ivan Franko National University of Lviv (2001). She was born in 1935 in Stryi in the family of Tadei and Maria Zaleskyi, who were teachers. In 1944, she and her parents were forced to leave Ukraine. First, they ended up in Slovakia, then in Austria, and eventually in West Germany, where they stayed for more than 3 years, which was their longest stay in one place. The toponyms of the German period of the scientist's life changed as in a kaleidoscope: Dresden, Leipzig, Frankfurt, Gattendorf, Pesnek, Augsburg (Sommer Caserne camp), NeuUlm (Reinhardt Caserne camp), Munich (Funk-Caserne camp), Bremen. In September 1948, the Zaleskyi family landed in Canada.

Larissa Zaleska Onyshkevych resided in the DP camps in West Germany at the age of 10-13. In Neu-Ulm, the girl studied at the Ukrainian gymnasium, where Dmytro Nytchenko taught the Ukrainian language, and Professor Leonid Biletskyi taught the Ukrainian literature. Not only Larissa succeeded academically, but she also took an active part in extracurricular activities. The young lady joined Plast, practiced piano, and made her debut on the camp radio citing Lesia Ukrainka's works. The future literary critic had progressive reading interests, for instance, there was George Orwell's "Animal Farm", which had just been translated into Ukrainian, in her library. By the way, this book was included into some of the Ukrainian camp schools' curriculums, and both adults and school children at DP camps discussed its key theses. Larissa's favorite consolation was to visit opera, the performances of the local camp theater called "Entertainment", and performances of other theaters that came on tour, for instance, the Ensemble of Ukrainian actors led by Volodymyr Blavatskyi, Yosyp Girniak's Theatric studio. The escape to the mentioned out-of-mundanity lacunas along with walks into the woods and infrequent excursions to West Germany enabled the girl to find solace in the difficult and hungry post-war years.

The DP era is an essential page in the history of Ukraine. One can be fascinated by the number of displaced persons and refugees from Ukraine, which in the year of 1945 constituted about 3 million (!) people. During the post-war transport collapse, unlike the Italians and French who tried to get from Germany to their homes even on foot, a significant part of displaced persons and refugees from Ukraine (as well 
IНТЕРМАРУМ: історія, політика, культура. - Вип. 8.

as from other USSR republics ) fiercely resisted returning to their "homeland". The semantics of this word is so dear and close to everyone from childhood. However, DP would critically put quotation marks every time they used this word, thereby emphasizing the threats they (being "traitors") would have faced if they had returned home. Despite the work of the Soviet repatriation commissions (which succeeded in repatriating most of the DP to the USSR) and propagandists, they deliberately trod the path of political emigration, held the line of their outposts (DP and refugees camps), and were getting ready to leave for the free world.

Meanwhile, having felt a certain ground under their feet, having found means of subsistence, having established a simple way of life, the campers who mostly were representatives of the intellectual class enthusiastically began to advance the Ukrainian way of life in West Germany. Shortly thereafter, apart from secondary schools there appeared higher educational establishments, scientific and art institutions, and several publishing houses, which published more than a dozen of newspapers and magazines. Scientists and teachers, participants of the National liberation struggle in Ukraine, former political prisoners of Stalin's camps stood up for the defense of DP and the historical memory of the Ukrainian people. For example, Ivan Bagrianyi, set forth forcibly the reasons why Ukrainians do not want to return to the USSR in the face of Western political elite. The others would regularly share the memories of important events in the national history with the campers, and speak about the National liberation struggle of the Ukrainian people from Cossack times to the middle of the twentieth century, as well as about outstanding people in the history and culture of Ukraine. Historians have always emphasized the importance of accumulating migrant laborers' memoirs. The intellectuals kept journals and actively corresponded with each other, thereby creating an array of privately owned sources, which later formed the basis of the DP era reminiscences.

Political emigrants realized that they were entrusted with an important mission to create a Ukrainian narrative about the events of the National liberation struggle of the first half of the twentieth century, Stalin's repressions, and their day-to-day routine in the DP camps. The first publications were published during the camp period. Then, once in 
INTERMARUM: history, policy, culture. - Issue 8.

America, Canada or Australia, they continued their scientific, journalistic and memoir activities. Mykola Verkhovynets, Vasyl Vytvytskyi, Ivanna Zelska, Semen Ishchyk, Ivan Kedryn, Zynovyi Knysh, Ivan Liutyi-Liutenko, Dmytro Nytchenko, Ulas Samchuk, Olexandr Skotsen published their DP era reminiscences abroad. The memoirs of Roman Volchuk, Halyna Voskobiinyk, Pylyp Haida, Vasyl Gryshko, Mykola Deichakovskyi, Hrygoryi Kostiuk, Kateryna Krychevska-Rosandich, Anatolyi Miroshnyk, Nataliia PolonskaVasylenko, Valeriian Revutskyi, Anatolyi Romaniuk, Adolf Slyzh, Mykola Sukhoverskyi, Leonid Khmelkovskyi, and Ivan Yurchenko have been recently published in Ukraine. The memoirs of Larissa Zaleska Onyshkevych, who currently lives in the United States, have a special place among them.

Apprehending the significance of the era in which she was destined to live and following her father's example, who regularly recorded events of their family life "on homemade calendars" (p. 251), Larissa Zaleska kept a journal. The school girl would succinctly write down important events from her life and impressions of what she had seen or experienced. Admittedly, it is a unique historical source, as such records of a one-off nature tend to have been written by adults. In those days, a school girl keeping a journal was rather an exception than the rule. It was the diary as well as the laconic notes of her father Tadei Zaleskyi that enabled Larissa Zaleska Onyshkevych to reconstruct the chronology and geography of her own odyssey in the DP era after more than half a century and write a book of memoirs in the XXI century.

The first book of memoirs by Larissa Zaleska Onyshkevych was published in English in the United States in 2016 (Larissa Zaleska Onyshkevych. "Borders, Bombs, and ... Two Right Shoes: World War II Through the Eyes of a Ukrainian Child Refugee Survivor. Charleston: Create Space; Amazon, 2016. 222 p.). The author translated the second book into Ukrainian in 2018 and published it in Ukraine. The books are almost identical in their content, although they have a few differences. The first one provides explanations of facts that may have been incomprehensible to English-speaking readers, while the second one adds information about famous figures who may be of interest to Ukrainian-speaking people. It contains stories about the life of Mykhailo and Maria Hrushevskyi, the daughter of Kobzar's nephew 
IНТЕРМАРУМ: історія, політика, культура. - Вип. 8.

Liudmyla Shevchenko (pp. 202-204). Both books primarily address the Ukrainians: the first one the descendants of the Ukrainian emigrants (as well as their American peers born not in the Ukrainian families), and the second one addresses those who live in Ukraine.

Structurally, the book consists of the preface and two parts, which are further divided into chapters. The first part, "My Journey during World War II" (pp. 19-189), covers the events from the winter of 1941 to the autumn of 1948, with small digressions into earlier times. The author tells the story of her family during World War II, which geographically covers Ukraine and Austria, West Germany in post-war times, and ends with her arrival in Canada. However, the main part of the text is devoted to her life in West Germany camps during 19451948.

The second part, "Consequences of Events from the Time before and after My Journey", contains some appendices. The first chapter "Explanations of the Background and Parallel Examples" (pp. 194-229) interprets separate terms, concepts, and events that were discussed in the first part of the book. It would have been possible to present those explanations in page-by-page footnotes, and in some places of the main text, but it is likely that the author decided not to overload it. The second chapter consists of appendices: the genealogical branch of the Shankovskyi family tree (p. 232); a chronological list of historical events in Ukraine that influenced the fate of the ancestors and relatives of the author of memoirs from the IX century to 2017 (p. 233-237); the main events in the Odyssey of Larissa Zaleska's ancestors on her mother's side (p. 238-240); a dictionary (p.241-250); acknowledgements (p. 251); an index of surnames and names (pp. 253257), however, without specifying page numbers (although they are present in the English version).

The peculiarity of Larissa Zaleska Onyshkevych's book of memoirs is that it presents the events from three perspectives, one of a teenager, a teacher, and a scientist.

It is what you learn about the life of a child in the DP era, what she lived through, what she felt and dreamed about, what factors made an impact on her worldview and civil position formation, as well as future professional activities that makes Larissa Zaleska Onyshkevych's book 
INTERMARUM: history, policy, culture. - Issue 8.

of memoirs, written on the basis of her journal entries made at the age of 10-13, peculiar among other published woks of the time.

The book provides an opportunity to look at the events of the Ukrainian "DP planet" through the eyes of a teenager, a student, and it significantly complements the memories of the artist Kateryna Krychevska-Rosandych (born in 1926), who graduated from the camp school in Mannheim in the spring of 1946. The memoirs of a school girl Larissa Zaleska, together with the published memoirs (Pylyp Haida, Dmytro Nytchenko, etc.) and the teachers' correspondence (Anna Cherin) create prerequisites for reconstructing the history of secondary educational institutions functioning during the DP era.

One can find a typical economic, social, cultural or political information about the DP era on the pages of the memoirs. At the same time, the memoirs also contain information that other memoir writers do not mention. It significantly increases the source value of the reviewed book. The book describes, for example, the stay of Lesia Ukrainka's elder sister Olga Kosach-Kryvyniuk (pp. 136-137, 226), about children's work (pp. 182-183) and leisure in the DP Sommer Caserne camp (Augsburg) (pp. 148-152, 154, 164-165), and about the functioning of the camp radio (pp. 158-159).

Larissa Zaleska Onyshkevych wrote her book of memoirs, pursuing primarily a didactic goal. The first edition of the memoirs is intended for the youth living in the United States (or for the entire English-speaking world in a broader context). This is the generation of Larissa's grandchildren, who encouraged her to write the memoirs (p. 252). Through her family story, the author tried to demonstrate the youth born in a democratic world the threats communism poses to humanity, to show the annihilation of dissidents by the Stalin's totalitarian system, as well as to emphasize the strength of the people's spirit, the invincibility of the Ukrainian people. The Ukrainian youth should regard these memoirs, alongside with informative appendices (chronological tables, a dictionary and maps of Ukraine and Germany), as the history of the native people, who were risen from the ashes like a phoenix and became stronger and tougher.

Reading Larissa Zaleska Onyshkevych's memoirs you cannot help but notice that one of the leitmotivs of her memoirs is the idea of humanity, humanism, helping others, forgiveness, assistance of friends 
IНТЕРМАРУМ: історія, політика, культура. - Вип. 8.

or strangers in solving everyday problems in Ukraine and in forced emigration, saving the human life at the risk of your own during the Holocaust, the ability to forgive enemies. The author argues that "wars do not kill humanity, it can flourish even under the most crushing and cruel circumstances" (p. 171). The human life and dignity are of the greatest value.

Despite the fact that Larissa Zaleska Onyshkevych's memoirs are based on her children's journal, the author used various sources to write the text as a real scientist. This is justified for a several reasons: firstly, 70 years have passed since the events described in her memoirs, and secondly, in her journal Larissa Zaleska would write down only the things that appealed to her as a 10- or 13-year-old girl. Therefore, not without reason it was necessary to verify separate facts and establish a chronology of events, so that the memoirs did not turn into a semidocumentary or semi-artistic work.

Among the sources used by the author were, firstly, sources of a private nature, namely the mentioned above journal of her father Tadei Zaleskyi, written in the second half of the 1940s, and the records of her mother, Maria Zaleska, about her family origin (the Shankovskyis), compelled in the 1970s. In addition, the author consulted some details with her relatives and friends who also were in DP camps (p. 251).

Secondly, the author used scientific works about World War II and the DP era, which allowed her to present the historical background of the events in the life of her family.

Thirdly, the book is abundant in photographs from the author's family archives and from her cousins' family albums, as well as it contains the illustrations from public sources that chronologically cover a period of about 100 years (late XIX - late XX centuries). Among them are the photos of the author and her family members, taken mainly in Ukraine and West Germany, photocopies of book covers and various documents. The certificate of professional courses completion (p. 179), the permission to settle in the DP camp (p. 137), the food cards (p. 115), the sheets from Larissa Zaleska's favorite poems handwritten anthology (1946-1948) (p. 148-149) and her school essay on the topic "The Saddest Day in My Life" (1948) (p. 20) are of particular interest among these documents. 
INTERMARUM: history, policy, culture. - Issue 8.

Compiling the chronicle of her family's life during World War II and the DP era, Larissa Zaleska Onyshkevych highlighted the important events not only in the history of Ukraine, but also in the world history through the prism of one single family. She considers the prerequisites for the beginning of the largest armed conflict in the world history, talks about the beginning of the German-Soviet war and the Nazi occupation of Ukraine, describes the everyday life under occupation, accounts for the persecution of the Ukrainian Greek Catholic Church by the Soviet authorities, the Holocaust, the phenomenon of collaboration, the creation of DP camps, and forced repatriation to the USSR. On the pages of her memoirs, there appear such outstanding figures of the Ukrainian history and culture as Mykhailo Hrushevskyi and Andrei Sheptytskyi, Lesia Ukrainka and Olga Kosach-Kryvyniuk, Olena Teliga and Leonid Biletskyi, Ivan Bagrianyi and Dmytro Nytchenko, Yosyp Girniak and Volodymyr Blavatskyi and many others.

In conclusion, it is worth mentioning that having published the book of memoirs "Bombs, Borders and Two Right Shoes. World War II Through the Eyes of a Refugee Child", Larissa Zaleska Onyshkevych joined the cohort of the Ukrainian memoir writers of the DP era. The published memoirs make it possible to look at the "Ukrainian DP planet" from both the child's and the scientist's perspectives, to get acquainted with its inhabitants, who lost their homeland but preserved their national identity and humanity, to learn about their fears and dreams, and to feel the psychological climate of the day. The book will be of interest primarily to researchers of World War II history, the history of displaced persons and Ukrainian refugees in West Germany. In addition, the book will be useful for those who research Larissa Zaleska Onyshkevych's life path and her multifaceted activities. The book of memoirs may be of interest to writers and filmmakers who want to reflect the DP era in their works.

Finally, I would like to recommend the author of the memoirs to publish her journal, written in the second half of the 1940s in West Germany, which is a unique source of private origin about the DP era. 
IНТЕРМАРУМ: історія, політика, культура. - Вип. 8.

\section{Подобєд Олена. ЕПОХА ДІПІ У РЕЦЕПЦІЯХ ДИТИНИ І НАУКОВЦЯ}

Рец.: Лариса Залеська Онишкевич. Бомби, границі $і$ два праві черевички. Друга світова війна очима дитини-біженця. Львів: Літопис, 2018. $258 \mathrm{c}$.

Доведено, щяо книга спогадів Лариси Залеської Онишкевич становить иінне джерело з історії переміщених осіб і біженців з України у повоєнній Західній Німеччині. 3 ї сторінок можна дізнатися, чим жила, що відчувала, про що мріяла, чого боялася дитина в епоху ДіПі, які фактори впливали на формування їі світогляду і громадянської позиції.

Ключові слова: Лариса Залеська Онишкевич, спогади, епоха ДіПі, Західна Німеччина.

\section{Podobied Olena. ERA OSÓB PRZEMIESZCZONYCH W PERCEPCJI DZIECKA I NAUKOWCY}

Recenzja: Larysa Zaleska Onyszkiewicz. Bomby, Granice i Dwa Prawe Buty. II wojna światowa oczami dzieci-uchodźców. Lwów: Litopys druk., 2018. $258 \mathrm{~s}$.

Udowodniono, że księga wspomnień Larysy Zaleskiej Onyszkiewicz jest cennym źródtem historii przesiedleńców i uchodźców z Ukrainy w powojennych Niemczech Zachodnich. Ze stron tej księgi można się dowiedzieć, czym żyly dzieci-uchodźcy, co czuly, o czym marzyly, czego się baty $w$ erze DP, jakie czynniki wptynęty na uksztaltowanie się ich światopoglądu $i$ pozycji obywatelskiej.

Stowa kluczowe: Larysa Zaleska Onyszkiewicz, wspomnienia, era DP, Niemcy Zachodnie.

The article was received 06. 02.2020 Article recommended for publishing 08.12.2020 